\title{
THE INFLUENCE OF ADVERTISING, PRICE, AND E- SERVICE QUALITY TO REPURCHASE INTENTION TO ONLINE TRAVEL AGENT USERS
}

\author{
Tonny Hendratono ${ }^{1}$, Supina $^{1}$, Suhendroyono $^{2}$, M. Syafulloh ${ }^{2}$, Andiko Priyono $^{2}$ \\ and Damiasih ${ }^{2}$ \\ ${ }^{1}$ Universitas Bunda Mulia, Jakarta, Indonesia \\ ${ }^{2}$ Sekolah Tinggi Pariwisata Ambarrukmo, Indonesia \\ thendratono@bundamulia.ac.id
}

\begin{abstract}
The Growth of the online travel agent is driven by the increase in Internet penetration, rise in disposable income of people in emerging markets, and ease of comparing a variety of travel options online. Market players are introducing innovative travel and vacation package deals to assist travelers' in making sound travel decisions as per their spending capability, such as affordable packages for international destination, discounts on car rentals and cash back on international flights. In Indonesia, the growth of Online Travel Agent is more than emerging, it is like a sky-jet, conventional travel agents in Indonesia realize that they cannot ignore the onslaught of Internet technology development along with its users. So, they are willing to add an online service system to their travel agent, therefore they need a suitable example of a well-established online travel agent, so they can adapt the positive aspects and fix the negative aspects. With technological advances, consumer behavior, supply chain support, and specific knowledge possessed by a conventional travel agent before, as they browse to the online world when they have the right strategy, they can become very powerful. Internet will no longer be a threat to conventional travel agents. Learning strategy from well-established online travel agents can be a perfect reference for conventional travel agents that will provide online service system on what matters will affect repurchase intention, then further explore and improve those aspects that can be learned as an example for its success in the future.
\end{abstract}

Keywords — Advertising, Price, E-Service Quality

\section{INTRODUCTION}

At the end of the 20th century the tourist industry is experiencing changes defining the direction of its development in the third millennium. These changes are so far reaching that one can speak about transformations in the nature of tourist business. Due to computer information technologies, a principally new type of relationship is developing among participants of the tourist market [1]. Where consumers now have the best of both worlds - they can book for themselves on the Internet or they can use the services of travel agents. It is not clear, however, that the Internet always provides a better solution than using a travel agency. Because of the expertise of travel agents, those who pay to use them may achieve savings and services that would offset the added cost of service charges. Agents have superior knowledge of the industry and are aware of various 
alternatives that can offer lower fares. They are far more likely than consumers to know enough to check alternative airports, or times of departures.

Moreover, they can easily search the Internet as well as their computer reservation systems for low fares. Since they are making reservation transactions throughout the day, and also have specialized web search tools, they can make such searches more efficiently than consumers. Once a booking is made, travel agents often continue to manage the client's travel, serving as an alert system, trouble shooter, and advocate with the travel supplier.

Many previous researches mostly concerned about the growth of online travel agent, giving the view that conventional travel agents will soon disappear Bogdanovych, et al., in [2], O'Connor and Frew in [3], and [4]. The conventional travel agent is dying, but it is not dead yet many corporate consumers are still loyal to conventional travel agent.

Incessant technological developments that occur even in the world cause the travel agent must be able to follow the development of technology that causes shifting behavior of buyers. And this is supported by The Association of Indonesian Aviation Ticket Agent Companies (Astindo), who directs its members to expand the online ticket sales business in 2015. Although, this is done because during the last two years the association members complained of reduced ticket sales through travel outlets due to the increasing number of new companies that provide online ticket purchase services [5]. Pauline Suharno, Deputy Secretary General of Astindo and owner of Elok Tour in Jakarta, said that since the proliferation of ticket sales through online ticketing companies such as Traveloka.com, Ticket.com, WeGo.com and so on, there has been a 20-30 percent decline in ticket sales. In order not to erode more deeply, Pauline said the association agreed to make joint ventures to serve the purchase of tickets online. "Currently the preparation stage such as who will be the ticket will be issued, who will handle the payment, who will take care of marketing, share the results of cooperation like what, to determine the vendor who will build the information technology system [6]. The decline in ticket sales is mainly triggered by a growing younger generation of internet. They prefer to buy plane tickets online because the process is faster and easier, no need to bother approaching ticket sales outlets as before [5]. With a one stop-shopping format, the presence of online travel agencies makes it easier for people to find their tourism needs, from tickets, lodging, tour packages, to travel insurance. "Online is practical, accessible anywhere. If offline system they must come to the office, " In connection with the willingness of The Association of Indonesian Aviation Ticket Agent Companies (Astindo) to keep up with the technology development by adding an online service system to their travel agents. It takes an appropriate online travel agency strategy analysis. They already threatened with online travel agent, when they now are willing to open themselves of online booking, but they follow the wrong online travel agent strategy.

Therefore, for analysis of the accuracy of the strategy used by Online Travel Agent is very important to be examined, similar research was conducted in 2016 by Dita Puspita Sari in Tangerang area, the same topic was tested for DKI Jakarta area. Traveloka, Indonesia's leading travel booking app for domestic and international destinations, which was awarded as the $1^{\text {st }}$ Most Powerful Indonesian Technology Brand and $1^{\text {st }}$ Most Innovative Brand may be the perfect benchmark to have a suitable strategy in running online travel agent business.

The rest of this paper is organized as follow: Section 2 describes the proposed theoretical framework. Section 3 describes the proposed research result. Finally, Section 4 concludes this work. 


\section{THEORETICAL FRAMEWORK}

\subsection{ADVERTISING}

According to Moriarty et al in [7], advertising is a form of paid communication that uses mass media and interactive media to reach a broad audience in order to connect clear sponsors with buyers (target audience) and provide information about products (goods, services , and ideas). According Moriarty, et al in [7], Table I below is how to measure the effectiveness of advertising based on the goals to be achieved and how consumers respond to various messages delivered.

Table I. The Facet of Effect Model

\begin{tabular}{|l|l|l|}
\hline \multicolumn{1}{|c|}{$\begin{array}{c}\text { Communication } \\
\text { objective }\end{array}$} & \multicolumn{1}{c|}{$\begin{array}{c}\text { Consumer } \\
\text { Response }\end{array}$} & \multicolumn{1}{c|}{ Drivers } \\
\hline Perception & See or hear & $\begin{array}{l}\text { exposure, selection, attention, interest } \\
\text { or relevance, awareness, recognition }\end{array}$ \\
\hline Emotion or Affective & Feel & $\begin{array}{l}\text { Want or desire, feeling, liking, } \\
\text { resonance }\end{array}$ \\
\hline Cognition & Understand & $\begin{array}{l}\text { Need, cognitive learning, } \\
\text { differentiation, recall }\end{array}$ \\
\hline Association & Connect & $\begin{array}{l}\text { Symbolism, conditioned learning, } \\
\text { transformation }\end{array}$ \\
\hline Persuasion & Believe & $\begin{array}{l}\text { Motivation, influence, involvement, } \\
\text { conviction, believability or } \\
\text { credibility, preference and intention, } \\
\text { loyalty }\end{array}$ \\
\hline Behavior & Act & $\begin{array}{l}\text { Trial, buying, contacting, advocating, } \\
\text { referral, prevention or avoidance }\end{array}$ \\
\hline
\end{tabular}

\subsection{PRICE}

Price is the sum of money that is billed on a product or service, or the sum of the value exchanged by customers to obtain the benefits of owning or using a product or service [8]. According to Morgan, et al. in [9], that prices have a major role in the buyer's decision-making process are: (1) The role of price allocation, the price function in helping buyers to decide how to obtain the highest expected benefits or utilities based on their purchasing power. Thus the price can help buyers to decide how to allocate their purchasing power to different types of goods or services. Buyers compare prices from the various alternatives available. (2) The role of information from the price, namely the function of pricing in educating consumer about product factors, such as quality. This is particularly useful in situations where the buyer has difficulty assessing the product or its benefits objectively. A common perception is that expensive prices reflect high quality so that consumers assess the price set according to the quality of the product or service set. Thus, the price can help buyers to decide how to allocate their purchasing power to different types of goods and services.

\subsection{E-SERVICE QUALITY}

"E-service has increasingly known as a critical channel through which customer needs can be automatically granted over internet throughout the consumption life cycle" [10]. "E-service quality is defined as meeting customer expectations without the service encounter relying on human-to-human interaction." [11]. The following dimensions of Eservice quality according to Valarie A et al in [12] are:

- Efficiency: the ease and speed of accessing and using this site. 
- Compliance: the extent to which site promises about order delivery and availability of products or services are met.

- Reliability: the correct technical function of the site.

- Privacy: the extent to which the site is secure and protect customer information.

\subsection{REPURCHASE INTENTION}

"Repurchase intention defined as the individual's judgement about buying again a designated service from the same company, taking into account his or her current situation and likely circumstances." [13]. Research conducted by Giffar in [14] on repurchase intention on Traveloka Travel Travel Agent, suggests measurement indicators of repurchase intention according to [15]:

- Consumers desire to return.

- The consumer's intention to recommend to others

- The product to be purchased becomes the first choice compared to other products.

\subsection{BUYING BEHAVIOR}

The purchase decision process emphasizes that the buying process starts long before the actual purchase and results long after the purchase. This encourages marketers to focus more on the overall buying process, rather than just paying attention to purchasing decisions. It can be said that the definition of consumer behavior is the process of time and level of business passed by consumers in determining a particular purchase decision depends on the importance of buying a product or service. [16].

\subsection{TRAVEL AGENT}

Travel Agent According to Diah in [17], Travel Agent is a business entity that organizes a travel business acting as an intermediary in selling or managing services to travel. The main products of travel agent are ticketing, hotel voucher, tour package, show voucher, and tour transportation. Hotels that work with travel agents will benefit a lot, as travel agents can actively promote the hotel to customers who use their services. The hotel will provide special price incentives and other rewards if it proves that the travel agent is productive. But in the cooperation there are some things that can be regarded as a loss, among others, is at the time the guests are in very crowded level, hotel room sales will not be optimal because the hotel should allocate part of the room to the travel agent. Optimization of room rates also will not be as high if the hotel sells all its rooms to other guests who dare to pay a high price.

\subsection{BENEFITS OF USING A TRAVEL AGENT}

Benefits are the 'get' components of value from the uni-dimensional perspective Zeithaml, in [18] and are obtained from value perceptions [19]. 'Benefits' are valuable or worthwhile outcomes received by the parties engaging in a relationship with each other [20]. According to social exchange theory, customers aim to maximize the benefits they receive from an exchange, to justify their costs. These benefits are both tangible and intangible [21]. Customer and supplier benefits have not received equal attention in marketing literature. To develop long-term relationships between customers and suppliers, mutual benefits must exist [22]. 


\subsection{METHODS AND TECHNIQUES DATA COLLECTION}

The method used in this research is multiple linear regression. The first step used is data quality test consisting of validity test and reliability test. After passing from the next data quality test using the classical assumption test consisting of normality test, multicollinearity test and heteroskedasticity test. Then after passing from the classical assumption test can be continued by testing the hypothesis consisting of $t$ test and $F$ test. Population and Sample: The population used is the consumer who is using Traveloka Online Travel Agent services. Because the population used is very large, sampling is done for this study. Vogt in [23], mentions that for descriptive and quantitative research, the required number of samples is 100 units. By following these guidelines, the study used the number of samples of 100 respondents di DKI Jakarta with convenience sampling method. Location and time of study: The research location is DKI Jakarta. The study was conducted in Jan-May 2017.

\section{RESULT AND DISCUSSION}

This section presents obtained results and following by discussion. Table II below presents respondent's socio-demographics.

Table II. Respondent's Socio-Demographics

\begin{tabular}{|c|c|c|c|}
\hline & & $n$ & $(\%)$ \\
\hline \multirow{2}{*}{ Gender } & Female & 72 & $72 \%$ \\
\hline & Male & 28 & $28 \%$ \\
\hline \multirow{5}{*}{ Age } & $17-25$ & 24 & $24 \%$ \\
\hline & $26-35$ & 43 & $43 \%$ \\
\hline & $36-45$ & 11 & $11 \%$ \\
\hline & $>45$ & 22 & $22 \%$ \\
\hline & Other & 15 & $15 \%$ \\
\hline \multirow{4}{*}{ Monthly Income } & $\begin{array}{c}\text { IDR } 0-\text { IDR } \\
500.000 \\
\end{array}$ & 0 & $0 \%$ \\
\hline & $\begin{array}{c}\text { IDR } 500.000-\text { IDR } \\
1.000 .000\end{array}$ & 3 & $3 \%$ \\
\hline & $\begin{array}{c}\text { IDR } 1.000 .000- \\
\text { IDR 5.000.000 }\end{array}$ & 23 & $23 \%$ \\
\hline & > IDR 5.000.000 & 74 & $74 \%$ \\
\hline \multirow{4}{*}{$\begin{array}{l}\text { OTA Purchase } \\
\text { Intensity in one year }\end{array}$} & 1 & 9 & $9 \%$ \\
\hline & $1-3$ & 27 & $27 \%$ \\
\hline & $4-6$ & 52 & $52 \%$ \\
\hline & $>6$ & 12 & $12 \%$ \\
\hline
\end{tabular}




\subsection{CLASSIC ASSUMPTION TEST RESULTS}

\section{A. DATA NORMALITY TEST RESULTS}

Normal P.P Plot of Regression Standardized Residual

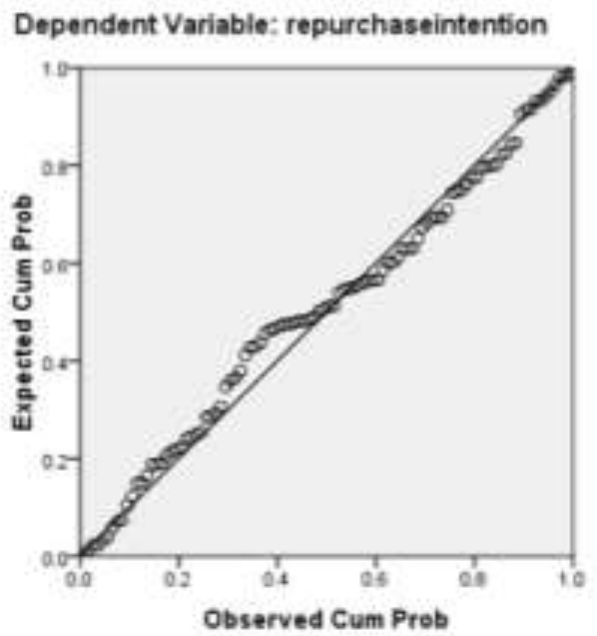

Fig. 1 Normality Results Are Graphs

Based on the Figure 1 above, it can be seen that the spreading dots around the diagonal line and the spreading data points in the direction of the diagonal line indicates that the regression assumption model meets the assumption of normality and regression model is feasible to analyze the influence of the independent variables (Advertising, Price and Eservice quality) to the dependent variable (Repurchase intention).

\section{B. MULTICOLLINEARITY TEST RESULTS}

Table III. Multicollinearity Test Results

\begin{tabular}{|c|c|c|c|}
\hline \multicolumn{2}{|c|}{} & \multicolumn{2}{c|}{ Collinearity Statistics } \\
\hline \multicolumn{2}{|c|}{ Model } & Tolerance & VIF \\
\hline 1 & (Constant) & & \\
\hline & Advertising & 0.801 & 1,944 \\
\cline { 2 - 4 } & Price & 0.742 & 1,447 \\
\cline { 2 - 4 } & E-Service Quality & 0.824 & 1,163 \\
\hline
\end{tabular}

From the results in Table III above can be stated multiple linear regression model there is no multicollinearity between the dependent variable with other independent variables.

\section{STATIC HETEROSCEDASTICITY TEST RESULT (GLESJER)}

Table IV. Static Heteroscedasticity Test Result (Glesjer)

\begin{tabular}{|l|l|l|}
\hline \multicolumn{2}{|c|}{ Model } & \multicolumn{1}{c|}{ Sig. } \\
\hline \multirow{3}{*}{1} & \multicolumn{1}{|c|}{ (Constant) } & 0.016 \\
\hline \multirow{3}{*}{} & Advertising & 0.032 \\
\cline { 2 - 3 } & Price & 0.044 \\
\cline { 2 - 3 } & E-Service Quality & 0.024 \\
\hline
\end{tabular}


It can be seen on Table IV above, because the level of significance is $>0.05$, it can be concluded that the regression model has no heteroscedasticity problem or in other words is free of heteroscedasticity

\subsection{HYPOTHESIS TEST RESULTS}

\section{A. PARTIAL SIGNIFICANT TEST RESULTS (T TEST)}

Table V. Partial Significant Test Results

\begin{tabular}{|l|l|c|c|}
\hline \multicolumn{2}{|c|}{ Model } & $t$ & Sig. \\
\hline 1 & (Constant) & 1.440 & 0.038 \\
\hline \multirow{5}{*}{} & Advertising & 2,832 & 0.003 \\
\cline { 2 - 4 } & Price & 2,246 & 0.002 \\
\cline { 2 - 4 } & E-Service Quality & 4,216 & 0.004 \\
\hline
\end{tabular}

From the results of the Table $\mathrm{V}$ above, on each independent variable significant value smaller than 0.05 so that the hypothesis on each independent variable is accepted, meaning that these three independent variables partially have a significant influence on Repurchase Intention.

\section{B. SIMULTANEOUS SIGNIFICANT TEST RESULTS ( $F$ TEST)}

Table VI. Simultaneous Significant Test Results

\begin{tabular}{|c|l|c|c|}
\hline \multicolumn{2}{|c|}{ Model } & $F$ & Sig. \\
\hline \multirow{4}{*}{1} & Regression & & \\
\cline { 2 - 2 } & Residual & \multirow{2}{*}{42,21} & $0.003^{\mathrm{a}}$ \\
\cline { 2 - 2 } & Total & & \\
\hline
\end{tabular}

From the Table VI above, data can be seen that the value of $F$ Research is greater than $F$ Table and the significant value smaller than 0.05 so that the regression model can be applied to the variable Repurchase Intention. In other words, it can be said that the variable of advertisement, price, and e-service quality simultaneously have significant influence to the repurchase intention variable.

\section{MULTIPLE REGRESSION TEST RESULTS}

Table VII. Multiple Regression Test Results

\begin{tabular}{|c|l|c|c|c|c|c|}
\hline \multirow{2}{*}{\multicolumn{2}{|c|}{ Model }} & \multicolumn{2}{c|}{$\begin{array}{c}\text { Unstandardized } \\
\text { Coefficients }\end{array}$} & $\begin{array}{c}\text { Standardized } \\
\text { Coefficients }\end{array}$ & $\mathrm{t}$ & Sig \\
\cline { 3 - 7 } & $\mathrm{B}$ & $\begin{array}{c}\text { Std. } \\
\text { Error }\end{array}$ & Beta & & \\
\hline 1 & (Constant) & -4.003 & & & 3.214 & 0.031 \\
\hline & Advertising & 0.287 & 0.048 & 0.143 & 2.445 & 0.039 \\
\hline & Price & 0.249 & 0.021 & 0.188 & 3.165 & 0.002 \\
\hline & E-Service Quality & 0.167 & 0.028 & 0.119 & 3.521 & 0.001 \\
\hline
\end{tabular}

Based on the results that have been obtained in Table 7 above, the regression equation is obtained as follows:

$$
Y=-4.003+0.287 X_{1}+0.249 X_{2}+0.167 X_{3}+e
$$

where:

$Y=$ Repurchase intention

$X_{1}=$ Advertising 
$X_{2}=$ Price

$X_{3}=$ E-Service Quality

$e=$ Standard Error

\section{DATA INTERPRETATIONS}

a. The constant of -4.003 means that if the advertising $\left(X_{1}\right)$, price $\left(X_{2}\right)$, and e-service quality $\left(X_{3}\right)$ variables are 0 then the repurchase intention value is -4.003 assuming other variables that may affect repurchase intention remain.

b. Advertising variable have a positive influence on repurchase intention with regression coefficient of 0.287 . This means that if the value of advertising variable increased by 1 unit then repurchase intention increased by 0.287 .

c. Price variable have a positive influence on repurchase intention with regression coefficient of 0.249 . This means that if the value of price variable increased by 1 unit then repurchase intention increased by 0.249 .

d. E-service quality variable has a positive influence on repurchase intention with regression coefficient of 0.167 . This means that if the value of e-service quality variable increased by 1 unit then repurchase intention increased by 0.167 .

\section{E. COEFFICIENT DETERMINATION TEST RESULTS (ADJUSTED R2)}

Table VIII. Coefficient Determination Test Results

\begin{tabular}{|c|c|}
\hline Model & Adjusted R Square \\
\hline 1 & 0.534 \\
\hline
\end{tabular}

From Table VIII above, the adjusted coefficient of determination or (Adjusted R2) is 0 . 534. This result means that independent variables: advertising, price and e-service quality can only give $53 \%$ influence on the dependent variable repurchase intention, while the remaining $47 \%$ other variables were not included in this model.

\section{CONCLUSIONS AND FUTURE WORK}

As a well-established online travel agent, study case of strategy on online travel agent applied in Traveloka proved that Advertising, Price and E-Service Quality have significant influence to consumer on Repurchase Intention, with an influence value of $53 \%$, means that half of repurchase intention based on online travel agent Advertising, Price, and E-Service Quality. The advertising of Traveloka even though the company is in Southeast Asian markets but is most heavily advertising in Indonesia, Thailand, and Vietnam, people in Indonesia can always see Traveloka advertisement everywhere in printed media, audiovisual media, visual media, even on many other online websites. Traveloka has the Best Price Guarantee as they will give consumer IDR 200.000. - if consumer finds out cheaper price in another websites. This also reinforces the image that Traveloka always provide the best price. Traveloka has the most complete package possible about E-Service Quality, not to mention their ease website visual and usage where we can not only to book but also to retrieve our booking over and over again (it will also send us short message service and email), they also have 24 hours customer service ready. Beating Traveloka on Advertising and Price may be hard as nowadays many Airlines and Hotels did not give special commission to travel agent, and the price is very competitive on this open market. But on E-Service Quality if a developing conventional travel agent hired the best web programmer, the staff of conventional travel agent could give the 4 components of E-Service Quality much even better with their knowledge about the whole and customized Airlines and Hotels' booking systems, such 
as: changing date when consumer is taking specific class, as on online travel agent we can only see the price without knowing on which class consumers will be seating, or the specific arrangement embedded on consumer's ticket.

In the future, still need to conduct research on another $47 \%$ other variables which is very influential to improve repurchase intention to this Traveloka websites as this will give a whole strategy package for a conventional travel agent to learn and even to another online travel agent. And the Conventional Travel Agent which will browse online to never forget that the consumer still loyal to conventional travel agent because of the personalized service that is given, not a template bookings. So, when a conventional travel agent serves online to never lose this personal touch to consumer.

\section{REFERENCES}

[1] Benckendorff, P. J., Xiang, Z., and Sheldon, P. J. (2019). Tourism information technology. Cabi Publishing.

[2] Bogdanovych, A., et al. "The role of online travel agents in the experience economy." Proceedings of the 14th International Conference on Information Technology and Travel \& Tourism (ENTER 2007). UK: Axon Imprint. 2007.

[3] O'Connor, Peter, and Andrew J. Frew. "The future of hotel electronic distribution: Expert and industry perspectives." Cornell Hotel and Restaurant Administration Quarterly 43.3 (2002): 33-45.

[4] Kasavana, M.L., and Singh, A. J. "Online auctions: dynamic pricing and the lodging industry." Journal of Hospitality \& Leisure Marketing 9.3-4 (2001): 127-140.

[5] Nhemachena, Charles, et al. "Climate change adaptation for rural communities dependent on agriculture and tourism in marginal farming areas of the Hwange District, Zimbabwe." African Journal of Agricultural Research 9.26 (2014): 2045-2054.

[6] Agoes, A., \& Dewi, S. W. R. (2018). Motivasi Konsumen Dalam Menggunakan Layanan Tiketing Di Agen Perjalanan Konvensional. Jurnal Sains Terapan Pariwisata, 3(2), 159-171.

[7] Moriarty, S., et al. Advertising: Principles and practice. Pearson Australia, 2014.

[8] Kotler, P., Burton, S., Deans, K., Brown, L., \& Armstrong, G. (2015). Marketing. Pearson Higher Education AU.

[9] Morgan, N. A., Whitler, K. A., Feng, H., \& Chari, S. (2019). Research in marketing strategy. Journal of the Academy of Marketing Science, 47(1), 4-29.

[10] Aghdaie, S. F. A., Dolatabadi, H. R., \& Aliabadi, V. S. "An analysis of impact of brand credibility and perceived quality on consumers' evaluations of brand alliance." International Journal of Marketing Studies 4.2 (2012): 93.

[11] Pearson, A., Tadisina, S., \& Griffin, C. "The role of e-service quality and information quality in creating perceived value: antecedents to web site loyalty." Information Systems Management 29.3 (2012): 201215.

[12] Zeithaml, V. A., Bitner, M. J., Gremler, D. D., \& Pandit, A. Services marketing: integrating customer focus across the firm. New York: McGraw-Hill, 2003.

[13] Hellier, P.K., et al. "Customer repurchase intention: A general structural equation model." European journal of marketing 37.11/12 (2003): 1762-1800.

[14] Giffar, Davinindya. "Peran Iklan, Brand Image, Price, Trust, dan Perceived Value Terhadap Repurchase Intention Traveloka." Jurnal Ilmiah Mahasiswa FEB 4.1 (2016).

[15] Peng, Luying, et al. "Butyrate enhances the intestinal barrier by facilitating tight junction assembly via activation of AMP-activated protein kinase in Caco-2 cell monolayers." The Journal of nutrition 139.9 (2009): 1619-1625.

[16] Boone, L. E., \& Kurtz, D. L. (2013). Contemporary marketing. Cengage learning.

[17] Pradiatiningtyas, D. "Analisa Buying Behavior Pada Online Travel Agent." Khasanah Ilmu-Jurnal Pariwisata Dan Budaya 6.2 (2015)

[18] Pananond, P., \& Zeithaml, C. P. "The international expansion process of MNEs from developing countries: a case study of Thailand's CP Group." Asia Pacific Journal of Management 15.2 (1998): 163184.

[19] Mathwick, C., Malhotra, N., \& Rigdon, E. "Experiential value: conceptualization, measurement and application in the catalog and Internet shopping environment." Journal of retailing 77.1 (2001): 39-56.

[20] Nielson, C.C. "An empirical examination of the role of "closeness" in industrial buyer-seller relationships." European Journal of Marketing 32.5/6 (1998): 441-463.

[21] Bagozzi, R. P. "Structural equation models in marketing research: Basic principles." Principles of marketing research3.1 (1994): 7-385.

[22] Coetsee, C., and Terblanche, E. "The time course of changes induced by resistance training and detraining on muscular and physical function in older adults." European Review of Aging and Physical Activity 12.1 (2015): 7.

[23] Vogt, W. P. (2007). Quantitative research methods for professionals. Boston: Pearson/allyn and Bacon. 
International Journal of Advanced Science and Technology Vol.130 (2019) 